CLINICAL STUDY

\title{
Pregnancy-associated plasma protein $A$ in obese children: relationship to markers and risk factors of atherosclerosis and members of the IGF system
}

\author{
Joachim Woelfle, Christian L Roth ${ }^{1}$, Rainer Wunsch ${ }^{2}$ and Thomas Reinehr ${ }^{3}$ \\ Pediatric Endocrinology Division, Children's Hospital, University of Bonn, Adenauerallee 119, 53113 Bonn, Germany, ${ }^{1}$ Seattle Children's Hospital \\ Research Institute, University of Washington, Seattle, Washington, USA and Departments of ${ }^{2}$ Pediatric Radiology and Ultrasound and ${ }^{3}$ Pediatric \\ Endocrinology, Diabetes and Nutrition Medicine, Vestische Hospital for Children and Adolescents Datteln, University of Witten/Herdecke, Witten, Germany \\ (Correspondence should be addressed to J Woelfle; Email: joachim.woelfle@ukb.uni-bonn.de)
}

\begin{abstract}
Background: Pregnancy-associated plasma protein A (PAPPA) is a large placenta-derived glycoprotein, which serves as a protease of several IGF-binding proteins (IGFBPs). In non-pregnant adults, measurable PAPPA levels were detected and have been implicated in the pathophysiology of atherosclerotic plaques. However, data in children is lacking.

Objective: To study the relationship between PAPPA, markers of atherosclerosis, and members of the IGF system in pediatric obesity.

Patients and design: Eighty-two obese and 52 nonobese children and 1-year longitudinal follow-up study for obese cohort.

Intervention: Outpatient 1-year intervention program based on exercise, behavior, and nutrition therapy.

Main outcome measures: Changes in PAPPA levels, carotid intima media thickness (IMT), weight, blood pressure, lipids, metabolic markers, and members of IGF system.

Results: Baseline PAPPA (PAPPA ${ }_{\mathrm{BL}}$ ) serum levels did not differ between obese and lean subjects. $\mathrm{PAPPA}_{\mathrm{BL}}$ correlated significantly with IGF1, IGFBP1, and serum cholesterol. During the 1-yearprogram mean IMT decreased from $0.66 \pm 0.01$ to $0.63 \pm 0.01 \mathrm{~mm}(P<0.05)$ and PAPPA from $1.83 \pm 0.12$ to $1.58 \pm 0.11 \mu \mathrm{U} / \mathrm{l}(P<0.00)$. In linear regression analysis with IMT after intervention as dependent variable, PAPPA contributed significantly to the observed variance. The longitudinal change of PAPPA correlated significantly with the change of serum triglycerides.

Conclusion: In this cohort of obese children, PAPPA serum levels correlated significantly with other cardiovascular risk factors. The lack of a direct correlation between PAPPA and IMT suggests that the described association of atherosclerotic plaques and increased PAPPA levels might reflect an indirect mechanism of PAPPA with cardiovascular risk factors such as serum lipids rather than a direct effect on the vasculature.
\end{abstract}

European Journal of Endocrinology 165 613-622

\section{Introduction}

Pregnancy-associated plasma protein A (PAPPA) is a zinc metalloproteinase identified in 1974 as a protein of placental origin in pregnant women (1). Subsequently, PAPPA proved to be a useful marker for Down syndrome during pregnancy (2). Besides the placenta as a major source of PAPPA during pregnancy, several studies reported expression of PAPPA in a number of tissues, such as testis, kidney, colon, (3), and expression during processes of injury repair and remodeling, e.g. in skin healing and vascular smooth muscle cells $(4,5)$.

Recent studies demonstrated that PAPPA acts as a protease degrading insulin-like growth factor-binding protein 2 (IGFBP2), 4, and 5 (6-9), thereby enhancing local IGF bioactivity. Several animal models underlined the role of PAPPA as a regulator of growth processes, with PAPPA-deficient animals exhibiting a growth phenotype resembling that of IGF2-deficient mice (10, 11). In contrast, overexpression of PAPPA increases somatic growth and skeletal muscle mass, paralleled by an increase in proteolysis of IGFBP4 and IGF bioavailability (12).

In 2001, Bayes-Genis et al. (5) implicated PAPPA in the development of acute coronary syndrome. Based on the function of PAPPA as a protease of IGFBPs, the authors suggested that PAPPA might contribute to progression of atherosclerosis through an increase in the local availability of IGF1. Since then, numerous studies demonstrated a role of PAPPA in the pathophysiology of atherosclerosis (13-15), although this has not been undisputed (16). As a putative explanation for 
controversial results, differences in assay composition have been suggested (17). In addition to increased concentrations in cardiovascular disease and increased concentrations of PAPPA have been described in diabetes (18). In adult patients with type 2 diabetes, a previous study found a significant correlation between serum PAPPA concentrations and intima media thickness (IMT) of the common carotid artery, an accepted noninvasive marker of early atherosclerosis (18). Furthermore, a previous study in adults with wellcontrolled type 2 diabetes found a relationship between glycemic control and serum PAPPA levels (19). We previously demonstrated that an increase in IMT can already be observed in childhood in obese compared with lean children (20).

In this study, we examine whether PAPPA serum concentrations differ between obese and lean children and whether PAPPA serum concentration in pediatric obesity is related to IMT, cardiovascular risk factors, and members of the IGF system. Furthermore, we are interested in changes of PAPPA and potentially related parameters during participation in a 1-year lifestyle intervention program.

\section{Methods}

We studied 82 obese children ( 38 who lost a substantial amount of their overweight and 44 obese children without weight change) over a 1-year period (see Table 1). Fifty-two nonobese healthy children served as controls. In the lean control group, we were able to take only one blood sample when the child's blood was taken for other reasons like during one of the screening visits. Therefore, we were able to determine differences regarding PAPPA and IGFBP4 at baseline, but none of the remaining biochemical parameters obtained in the obesity group and after 1 year.

Written informed consent was obtained from all children and their parents. The study was approved by the local ethics committee of the University of Witten/Herdecke in Germany.

Table 1 Age, weight status (body mass index (BMI) and SDS-BMI), height, sex ratio, and pubertal stage in obese and nonobese children. Data are presented as mean \pm S.E.M. or percentage.

\begin{tabular}{lccr}
\hline & Obese & Nonobese & \multicolumn{1}{c}{$\boldsymbol{P}$} \\
\hline No. & 82 & 52 & \\
Age (years) & $10.7 \pm 0.3$ & $11.1 \pm 0.4$ & 0.362 \\
Weight $(\mathrm{kg})$ & $65.3 \pm 2.1$ & $36.4 \pm 1.8$ & $<0.001$ \\
BMl $\left(\mathrm{kg} / \mathrm{m}^{2}\right)$ & $28.0 \pm 0.4$ & $17.0 \pm 0.3$ & $<0.001$ \\
BMI-SDS & $2.5 \pm 0.0$ & $-0.4 \pm 0.1$ & $<0.001$ \\
Height $(\mathrm{cm})$ & $150.8 \pm 1.7$ & $143.3 \pm 2.8$ & 0.018 \\
Height-SDS & $0.85 \pm 0.1$ & $-0.57 \pm 0.2$ & $<0.001$ \\
Sex & $48.8 \%$ male & $55.8 \%$ male & 0.434 \\
Pubertal stage & $52.4 \%$ prepubertal & 46.2 prepubertal & 0.617 \\
PAPPA $(\mu \mathrm{U} / \mathrm{l})$ & $1.83 \pm 0.22$ & $1.81 \pm 0.12$ & 0.939 \\
IGFBP4 $(\mu \mathrm{g} / \mathrm{l})$ & $432.5 \pm 11.4$ & $330.9 \pm 12.6$ & $<0.001$ \\
\hline
\end{tabular}

The obese children were studied before and after participating in the 1-year lifestyle intervention 'Obeldicks', which has been described in detail elsewhere $(21,22)$. Briefly, this outpatient intervention program for obese children is based on physical exercise, nutrition education, and behavior therapy including individual psychological care of the child and his or her family. The nutritional course is based on a fat- and sugar-reduced diet compared to the everyday nutrition of German children.

None of the children in the cohort of the current study suffered from endocrine disorders including type 2 diabetes mellitus, premature adrenarche, or syndromal obesity. All were non-smokers without any regular medication.

Obesity was defined according to the recommendation of the International Task Force of Obesity using population-specific data $(23,24)$. Height was measured to the nearest centimeter using a rigid stadiometer. Weight was measured in underwear to the nearest $0.1 \mathrm{~kg}$ using a calibrated balance scale. Because the distribution of body mass index (BMI) is not comparable in children and adults, not even among the various childhood age groups, we used the LMS method to calculate SDS-BMI as a measurement for the degree of overweight. The LMS method was chosen as it summarizes the data in terms of three smooth agespecific curves called lambda (L), mu (M), and sigma (S) based on German population-specific data $(24,25)$. The $\mathrm{M}$ and $\mathrm{S}$ curves, respectively, correspond to the median and coefficients of variation (CV) of BMI for German children at each age and gender, whereas the L curve allows for the substantial age-dependent skewness in the distribution of BMI $(24,25)$. The assumption underlying the LMS method is that after Box-Cox power transformation, the data at each age are normally distributed (25). Using the LMS calculation method described above, substantial weight loss in the course of 1 year was defined as a reduction of SDS-BMI $>0.5$, because with a reduction of $<0.5$ SDS-BMI no improvement of insulin resistance and cardiovascular risk factors could be detected in obese children participating in this lifestyle intervention program (21).

The pubertal developmental stage was determined according to Marshall \& Tanner $(26,27)$ and categorized into two groups (prepubertal: boys with pubic hair and gonadal stage I, girls with pubic hair stage and breast stage I; pubertal: boys with pubic hair or gonadal stage $\geq \mathrm{II}$, and pubertal girls with pubic hair stage or breast stage $\geq$ II).

Blood pressure was measured according to the guidelines of the National High Blood Pressure Education Program (NHBPEP) (28). Systolic blood pressure (SBP) and diastolic blood pressure (DBP) were measured twice at the right arm after a $10 \mathrm{~min}$ rest in the supine position using a calibrated sphygmomanometer and averaged. The cuff size of the sphygmomanometer used, based on the length and 
circumference of the upper arm, was as large as possible without having the elbow skin crease obstruct the stethoscope (28).

Blood sampling was performed in the fasting state at $0800 \mathrm{~h}$. All serum samples were frozen opaque at $-81^{\circ} \mathrm{C}$ and thawed only once. All measurements were performed in duplicates and averaged.

PAPPA was measured with a specific ELISA (Diagnostic System Laboratories, Inc., Webster, TX, USA; DSL-1027600). This assay uses an antibody pair that measures dimeric, uncomplexed PAPPA, and PAPPA/pro major basic protein (proMBP) in equimolar concentrations. The minimum detection limit was $0.18 \mu \mathrm{U} / \mathrm{ml}$; intraand inter-assay $\mathrm{CV}$ were $<10 \%$. IGF1 was measured with a highly specific chemiluminescence immunoassay (Immulite 1000 IGF1, Diagnostic Products Corporation, Los Angeles, CA, USA) without detectable cross-reactions to proinsulin, insulin, and IGF2. The sensitivity was $20 \mathrm{ng} / \mathrm{ml}$. Intra- and inter-assay $\mathrm{CV}$ were $<6 \%$.

IGFBP1 levels were assessed by a sandwich ELISA utilizing two specific high-affinity antibodies for this protein (IGFBP1 ELISA Mediagnost, Tuebingen, Germany). Serum was appropriately diluted to measure within the linear range of the assay. The sensitivity of the assay is $0.02 \mathrm{ng} / \mathrm{ml}$; intra- and inter-assay $\mathrm{CV}$ were $<10 \%$.

IGFBP3 was measured with highly specific chemiluminescence immunometric assay (Immulite IGFBP3, Diagnostic Products Corporation) without any crossreactions to IGF2, IGFBP1, and IGFBP2. The sensitivity was $0.02 \mu \mathrm{g} / \mathrm{ml}$. Intra- and inter-assay CV were $<10 \%$. IGFBP4 was measured with a specific ELISA (Diagnostic System Laboratories, Inc.; DSL-10-7300). The minimum detection limit was $0.008 \mathrm{ng} / \mathrm{ml}$; intra- and interassay $\mathrm{CV}$ were $<10 \%$.

Insulin concentrations were measured by microparticle-enhanced immunometric assay (Abbott, Wiesbaden, Germany). Glucose levels were determined by colorimetric test using a Vitros analyzer (Ortho Clinical Diagnostics, Neckargemund, Germany). HDL-cholesterol concentrations were measured by an enzymatic test (HDL-C-Plus Roche Diagnostics) and triglyceride concentrations by a colorimetric assay using a Vitros analyzer (Ortho Clinical Diagnostics). Homeostasis model assessment (HOMA) was calculated by the following formula: resistance $(\mathrm{HOMA})=($ insulin $(\mathrm{mU} / \mathrm{l}) \times$ glucose $(\mathrm{mmol} / \mathrm{l})) / 22.5$ (29).

Waist circumference was measured at the narrowest point between the lower rib and the iliac crest during expiration.

We measured IMT by B-mode ultrasound using a $14 \mathrm{MHz}$ linear transducer following a standardized protocol. The measurement was performed at the common carotid artery (CCA) near the bifurcation at the far wall. We measured four values on each side and took the maximum value for statistical purposes because the strongest association between the different measurements of IMT and coronary risk factors in otherwise healthy individuals is achieved by applying the maximum and not the mean value of IMT (30). The patients were examined in the supine position with the head turned slightly to the side. The same sonographer, who was blinded to the participants' cardiovascular risk factor status, performed all the examinations. In none of the examined patients, we found evidence of plaque.

Statistical analyses were performed using the SPSS Software package, version 17.0. Student's t-test for paired and unpaired observations of normally distributed values and for non-normally distributed variables Wilcoxon and Mann-Whitney $U$ tests were used when appropriate. Mean values of variables were expressed as mean and s.E.M. Correlations between parameters were calculated by Pearson's correlation coefficient for parameters following a normal distribution and by Spearman's rank coefficient for nonparametric parameters, as tested by the Kolmogorov-Smirnov test. Partial correlations, adjusted for gender, pubertal stage, and age, between changes of PAPPA, IGF1, IGFBP1, 3, 4, serum lipids, fasting glucose and insulin, and anthropometric variables in the course of 1 year were calculated. Parameters that did not follow a normal distribution were log-transformed prior to analysis. Changes were expressed as delta variable calculated by variable at baseline minus variable measured 1 year later. Multiple logistic regression analyses with IMT as a dependent variable including PAPPA, IGF1, IGFBP1, 3, 4, fasting insulin and glucose, triglycerides, total cholesterol, high density lipoprotein (HDL), low density lipoprotein (LDL), blood pressure, age, sex, and pubertal stage were calculated. A $P$ value $<0.05$ was considered as significant; $P$ values between 0.05 and 0.1 were considered as indicators of a trend.

\section{Results \\ Cross-sectional analyses}

Obese patients and lean controls did not differ regarding age, gender, and pubertal stage. By definition, BMI and BMI-SDS were significantly higher in the obese group. In addition, obese children were moderately taller with a significantly higher height-SDS (see Table 1).

IGFBP4 was significantly higher in obese children, whereas baseline PAPPA $\left(\mathrm{PAPPA}_{\mathrm{BL}}\right.$ ) serum levels did not differ between obese and lean subjects (Table 1). In

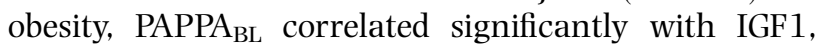
IGFBP1, and serum cholesterol, but not with IGFBP 3 or 4 serum levels. In addition, IGFBP4 correlated significantly with fasting insulin and HOMA as markers of insulin sensitivity (see Table 2). In lean subjects, PAPPA did not correlate to IGFBP4 or clinical/axiological parameters such as BMI, height, age, or pubertal stage.

At baseline, we found no correlation between PAPPA $\mathrm{BL}_{\mathrm{BL}}$ and age, BMI-SDS, waist circumference, IMT, and blood pressure (both SBP and DBP) in obese subjects. We found no differences of PAPPA $\mathrm{BL}$ in prepubertal and 
Table 2 Correlation of baseline PAPPA, IGFBP4 with other members of the IGF system, plasma lipids, and markers of insulin sensitivity (Spearman's correlation coefficients) in obese children. Numbers in bold indicate statistically significant correlations.

\begin{tabular}{|c|c|c|c|c|c|c|c|c|c|c|c|}
\hline & & IGFBP4 & IGF1 & IGFBP1 & IGFBP3 & Insulin & HOMA & Cholesterol & Triglycerides & HbA1c & Glucose \\
\hline \multirow[t]{2}{*}{ PAPPA } & $r$ & -0.127 & -0.263 & 0.371 & 0.082 & 0.119 & -0.132 & 0.241 & 0.116 & 0.010 & -0.126 \\
\hline & $P$ & NS & 0.026 & 0.004 & NS & NS & NS & 0.033 & NS & NS & NS \\
\hline \multirow[t]{2}{*}{ IGFBP4 } & $r$ & & 0.172 & -0.230 & 0.366 & 0.367 & 0.347 & 0.022 & 0.426 & 0.218 & 0.034 \\
\hline & $P$ & & NS & 0.077 & 0.002 & 0.001 & 0.003 & NS & 0.000 & 0.074 & NS \\
\hline \multirow[t]{2}{*}{ IGF1 } & $r$ & & & -0.554 & 0.457 & 0.257 & 0.264 & 0.009 & 0.149 & 0.000 & 0.161 \\
\hline & $P$ & & & 0.000 & 0.000 & 0.026 & 0.022 & NS & NS & NS & NS \\
\hline \multirow[t]{2}{*}{ IGFBP1 } & $r$ & & & & -0.299 & -0.574 & -0.598 & -0.112 & -0.281 & -0.014 & -0.228 \\
\hline & $P$ & & & & 0.025 & 0.000 & 0.000 & NS & 0.030 & NS & 0.080 \\
\hline \multirow[t]{2}{*}{ IGFBP3 } & $r$ & & & & & 0.257 & 0.253 & 0.305 & 0.331 & -0.005 & 0.073 \\
\hline & $P$ & & & & & 0.026 & 0.029 & 0.008 & 0.004 & NS & NS \\
\hline \multirow[t]{2}{*}{ Insulin } & $r$ & & & & & & 0.991 & 0.044 & 0.470 & 0.009 & 0.334 \\
\hline & $P$ & & & & & & 0.000 & NS & 0.000 & NS & 0.002 \\
\hline \multirow[t]{2}{*}{ HOMA } & $r$ & & & & & & & 0.059 & 0.454 & 0.010 & 0.453 \\
\hline & $P$ & & & & & & & NS & 0.000 & NS & 0.000 \\
\hline \multirow[t]{2}{*}{ Cholesterol } & $r$ & & & & & & & & 0.329 & 0.213 & 0.028 \\
\hline & $P$ & & & & & & & & 0.003 & 0.063 & NS \\
\hline \multirow[t]{2}{*}{ Triglycerides } & $r$ & & & & & & & & & 0.005 & 0.065 \\
\hline & $P$ & & & & & & & & & NS & NS \\
\hline \multirow[t]{2}{*}{ Glucose } & $r$ & & & & & & & & & & 0.027 \\
\hline & $P$ & & & & & & & & & & NS \\
\hline
\end{tabular}

pubertal subjects $(1.7 \pm 1.1 \mu \mathrm{U} / \mathrm{l}$ in prepuberty versus $2.0 \pm 1.1 \mu \mathrm{U} / \mathrm{l}$ in pubertal subjects; $P=0.19)$. At baseline, $\mathrm{PAPPA}_{\mathrm{BL}}$ did not differ significantly between obese girls and boys ( $1.7 \pm 0.2$ vs $2.0 \pm 0.2 \mu \mathrm{U} / \mathrm{l} ; P>0.05)$. However, PAPPA after intervention was significantly lower in girls compared with boys $(1.3 \pm 0.1$ in girls versus 1.9 $\pm 0.2 \mu \mathrm{U} / \mathrm{l}$ in boys; $P=0.002$ ).

In multiple logistic regression analysis, insulin and serum lipids (both cholesterol and triglycerides), but not PAPPA, contributed significantly to the observed variance in IMT before participation in the intervention program. However, after participating in the program, not only fasting insulin and triglycerides but also PAPPA and fasting glucose contributed significantly to the observed variance in IMT (Table 3). In subgroup analysis comparing the groups with and without significant weight loss, we found a significant contribution of PAPPA levels to the variance of IMT after intervention only in individuals with weight loss (Table 4). However, subgroup analyses lead to relatively small group sizes; therefore, these results warrant confirmation in larger sized cohorts.

\section{Longitudinal analyses}

Thirty-eight of the 82 obese children showed a significant weight loss (defined as a decrease more than 0.5 BMI-SDS; see Table 5). Regarding weight, a decrease from $60.5 \pm 2.6$ to $58.6 \pm 2.5 \mathrm{~kg}$ was observed for this subgroup, reflecting a mean weight loss of

Table 3 Multiple backward linear regression analysis with IMT before (A) and after 1 year (B) as the dependant variable and age, sex (0, female; 1 , male), pubertal stage ( 0 , prepubertal; 1 , pubertal), systolic and diastolic blood pressures (SBP and DBP), IGF1, IGFBP1, 3, 4, PAPPA, fasting insulin and glucose, HbA1c, cholesterol, -HDL, -LDL, and triglycerides as independent variables in 82 obese children.

\begin{tabular}{|c|c|c|c|c|c|c|}
\hline & \multicolumn{6}{|c|}{ Variables } \\
\hline & $\beta$ & $\beta S E$ & Standard $\beta$ & Partial corr. & $P$ & Corr. model $r^{2}$ \\
\hline (A) IMT before 1 year & & & & & & 0.452 \\
\hline Intercept & 0.094 & 0.028 & & & & \\
\hline Insulin & 0.009 & 0.002 & 0.613 & 0.650 & 0.000 & \\
\hline IGFBP3 & 0.004 & 0.009 & 0.234 & 0.300 & 0.036 & \\
\hline $\mathrm{HbA} 1 \mathrm{c}$ & -0.024 & 0.017 & -0.218 & -0.381 & 0.028 & \\
\hline Triglycerides & -0.001 & 0.001 & -0.313 & -0.285 & 0.007 & \\
\hline (B) IMT after 1 year & & & & & & 0.554 \\
\hline Intercept & 0.147 & 0.037 & & & & \\
\hline Insulin & 0.010 & 0.002 & 0.520 & 0.491 & 0.000 & \\
\hline IGFBP3 & 0.001 & 0.000 & 0.234 & 0.256 & 0.075 & \\
\hline $\mathrm{HbA1c}$ & -0.003 & 0.002 & -0.235 & -0.310 & 0.030 & \\
\hline Triglycerides & -0.039 & 0.002 & -0.196 & -0.315 & 0.047 & \\
\hline
\end{tabular}


Table 4 Multiple backward linear regression analysis with IMT after participation as the dependant variable and age, sex (0, female; 1 , male), pubertal stage (0, prepubertal; 1 , pubertal), systolic/diastolic blood pressure (SBP and DBP), IGF1, IGFBP1, 3, 4, PAPPA, fasting insulin and glucose, $\mathrm{HbA1c}$, cholesterol, -HDL, -LDL, and triglycerides as independent variables in obese children with (A) and without (B) significant weight loss.

\begin{tabular}{|c|c|c|c|c|c|c|}
\hline & \multicolumn{6}{|c|}{ Variables } \\
\hline & $\beta$ & $\beta S E$ & Standard $\beta$ & Partial corr. & $P$ & Corr. model $r^{2}$ \\
\hline \multicolumn{7}{|c|}{ (A) Obese children with significant weight loss } \\
\hline IMT & & & & & & 0.423 \\
\hline Intercept & 0.157 & 0.039 & & & & \\
\hline PAPPA & -0.004 & 0.001 & -0.506 & -0.669 & 0.003 & \\
\hline Insulin & 0.010 & 0.004 & 0.568 & 0.549 & 0.022 & \\
\hline Triglycerides & 0.000 & 0.000 & 0.527 & 0.604 & 0.010 & \\
\hline IGFBP1 & 0.005 & 0.002 & 0.572 & 0.561 & 0.019 & \\
\hline IGFBP3 & 0.003 & 0.002 & 0.337 & 0.471 & 0.056 & \\
\hline LDL & 0.000 & 0.000 & 0.356 & 0.512 & 0.036 & \\
\hline Pubertal stage & -0.006 & 0.003 & -0.341 & -0.477 & 0.053 & \\
\hline Sex & -0.012 & 0.004 & -0.645 & -0.650 & 0.005 & \\
\hline \multicolumn{7}{|c|}{ (B) Obese children without significant weight loss } \\
\hline IMT & & & & & & 0.651 \\
\hline Intercept & 0.163 & 0.114 & & & & \\
\hline PAPPA & 0.014 & 0.010 & 0.539 & 0.540 & 0.017 & \\
\hline Insulin & 0.008 & 0.004 & 0.520 & 0.640 & 0.038 & \\
\hline Fasting glucose & -0.047 & 0.004 & 0.600 & -0.425 & 0.070 & \\
\hline Triglycerides & 0.001 & 0.000 & 4.699 & 0.456 & 0.003 & \\
\hline Total cholesterol & -0.005 & 0.002 & -9.417 & -0.464 & 0.045 & \\
\hline $\mathrm{HDL}$ & 0.004 & 0.002 & 3.567 & 0.456 & 0.053 & \\
\hline LDL & 0.004 & 0.002 & 8.588 & 0.453 & 0.052 & \\
\hline RRsys & 0.000 & 0.000 & -0.418 & 0.453 & 0.052 & \\
\hline Sex & 0.026 & 0.024 & -0.387 & 0.479 & 0.049 & \\
\hline
\end{tabular}

$2.9 \%$. In contrast, in the subgroup of 44 children without significant weight loss, weight increased from $69.5 \pm 3.0$ to $77.0 \pm 3.3 \mathrm{~kg}$, reflecting a mean weight gain of $11.3 \%$ (see Table 5 ).

In the longitudinal analyses in the course of 1 year, in obese children with and without weight loss, IMT decreased significantly (delta IMT; $0.03 \pm 0.01 \mathrm{~mm}$; $P<0.05)$. In a power analysis on the decrease of IMT, we had a power of 0.999 based on a mean difference of $0.11 \pm 0.05 \mathrm{~mm}$ in the 42 children with substantial weight loss, a two-side test, and an $\alpha$ error of 0.05 . Correspondingly, PAPPA serum levels decreased from $1.83 \pm 0.12$ to $1.58 \pm 0.11 \mu \mathrm{U} / \mathrm{l}$, whereas IGFBP4 did not change significantly $(P<0.005$ for PAPPA; see Fig. 1).

In the 38 children who showed a significant weight loss, markers of insulin sensitivity improved significantly and serum lipids showed a significant decrease (Table 5). Correspondingly, after 1 year ( $1 \mathrm{y})$, IMT (baseline $0.66 \pm 0.00$ vs 1 y $0.55 \pm 0.00 \mathrm{~mm}$; $P=0.000$ ), SBP (baseline $118.5 \pm 2.2$ vs 1 y 109.3 $\pm 2.0 \mathrm{mmHg} ; P=0.004$ ), DBP (baseline $67.6 \pm 2.1$ vs 1 y $62.5 \pm 1.4 \mathrm{mmHg} ; P=0.016)$, and waist circumference (baseline $86.5 \pm 1.7$ vs 1 y $81.3 \pm 1.7 \mathrm{~mm}$; $P=0.002$ ) decreased significantly.

In the 44 obese children in whom no significant weight loss could be observed, neither insulin sensitivity nor serum lipids improved (Table 3B). Regarding clinical parameters, IMT increased $\left(\mathrm{IMT}_{\mathrm{BL}} 0.65 \pm 0.00\right.$ vs $\mathrm{IMT}_{\text {after 1 y }} 0.69 \pm 0.00 \mathrm{~mm} ; P<0.001$ ), whereas RRsys (systolic blood pressure) $\left(\mathrm{RR}_{\mathrm{BL}} 117.7 \pm 2.3\right.$ vs $\mathrm{RR}_{\mathrm{after}} 1 \mathrm{y}$ $115.1 \pm 2.2 \mathrm{mmHg} ; P>0.05)$, RR dias $\left(\mathrm{RR}_{\mathrm{BL}} 66.9\right.$ \pm 1.7 vs $\left.R_{\text {after } 1 \text { y }} 66.3 \pm 1.5 \mathrm{mmHg} ; P>0.05\right)$, or waist circumference $\left(\mathrm{WC}_{\mathrm{BL}} 92.9 \pm 2.1\right.$ vs $\mathrm{WC}_{\text {after } 1 \mathrm{y}}$ $92.9 \pm 2.2 \mathrm{~mm} ; P>0.05)$ changed significantly.

Serum PAPPA concentration decreased in both groups during the 1-year program. Mean serum PAPPA concentration after participation in the weight loss program was lower in the group with significant weight loss compared with children without weight loss (1.45 vs $1.69 \mu \mathrm{U} / \mathrm{l}$; see Table 5), although this difference showed only a trend of statistical significance $(P=0.06)$.

In the 1-year follow-up period, the changes in PAPPA correlated significantly to changes in triglycerides $(r=0.243, P=0.017)$, but not to changes in cholesterol $(r=-0.03, P=0.491)$, changes in fasting glucose $(r=$ $0.031 ; P=0.399)$, changes in fasting insulin $(r=0.011$; $P=0.463)$, changes in IGF1 $(r=-0.045 ; P=0.362)$, changes in IGFBP1 $(r=-0.085 ; P=0.269)$, changes in IGFBP3 $(r=0.132 ; P=0.147)$, and changes in IGFBP4 $(r=0.123 ; P=0.155)$.

\section{Discussion}

This study provides for the first time data on PAPPA and one of its putative substrates, IGFBP4, in obese and lean children and sheds light on the relationship of PAPPA with markers and risk factors of atherosclerosis in obese 
Table 5 Change in height and weight status (BMI, SDS-BMI, and SDS-height), PAPPA, members of the IGF system, and plasma lipids in 38 obese children with substantial (decrease in SDS-BMI $>0.5$ ) weight loss (group 1 ) and in 44 obese children without substantial (decrease in SDS-BMI <0.5) weight loss (group 2) over a 1-year period. Data are presented as mean \pm S.E.M.

\begin{tabular}{|c|c|c|c|c|c|c|}
\hline & \multicolumn{3}{|c|}{ Group 1} & \multicolumn{3}{|c|}{ Group 2} \\
\hline & Baseline & 1-year follow-up & $P$ & Baseline & 1-year follow-up & $P$ \\
\hline BMI & $27.2 \pm 3.5$ & $24.2 \pm 3.5$ & 0.000 & $28.8 \pm 7.1$ & $29.8 \pm 7.5$ & 0.000 \\
\hline BMI-SDS & $2.4 \pm 0.06$ & $1.8 \pm 0.07$ & 0.000 & $2.5 \pm 0.06$ & $2.5 \pm 0.06$ & 0.729 \\
\hline Weight (kg) & $60.5 \pm 2.6$ & $58.6 \pm 2.5$ & 0.003 & $69.5 \pm 3.0$ & $77.0 \pm 3.3$ & 0.000 \\
\hline Height SDS & $0.55 \pm 0.1$ & $0.65 \pm 0.1$ & 0.081 & $1.1 \pm 0.1$ & $1.0 \pm 0.1$ & 0.156 \\
\hline Waist circumference $(\mathrm{cm})$ & $86.5 \pm 1.7$ & $81.3 \pm 1.7$ & 0.002 & $92.9 \pm 2.1$ & $92.9 \pm 2.2$ & 0.984 \\
\hline PAPPA $(\mu \mathrm{U} / \mathrm{I})$ & $1.65 \pm 0.2$ & $1.45 \pm 0.2$ & 0.192 & $1.98 \pm 0.2$ & $1.69 \pm 0.1$ & 0.038 \\
\hline IGFBP4 ( $\mu \mathrm{g} / \mathrm{l})$ & $424.9 \pm 19$ & $414.9 \pm 15$ & 0.546 & $440.0 \pm 13$ & $465.8 \pm 15$ & 0.075 \\
\hline IGFBP1 (ng/ml) & $4.5 \pm 0.7$ & $5.3 \pm 1.4$ & 0.414 & $4.2 \pm 1.1$ & $3.0 \pm 0.6$ & 0.016 \\
\hline IGFBP3 ( $\mu \mathrm{g} / \mathrm{ml})$ & $5.3 \pm 0.2$ & $5.5 \pm 0.2$ & 0.340 & $5.7 \pm 0.2$ & $5.7 \pm 0.2$ & 0.859 \\
\hline IGF1 (ng/ml) & $280.9 \pm 32.1$ & $326.5 \pm 25.3$ & 0.039 & $260.5 \pm 21.4$ & $330.7 \pm 29.7$ & 0.000 \\
\hline Fasting glucose $(\mathrm{mg} / \mathrm{dl})$ & $83.8 \pm 1.4$ & $88.8 \pm 4.5$ & 0.329 & $83.8 \pm 1.2$ & $85.9 \pm 1.1$ & 0.125 \\
\hline Insulin (mU/I) & $16.0 \pm 1.5$ & $11.6 \pm 1.3$ & 0.004 & $20.0 \pm 2.1$ & $22.3 \pm 2.4$ & 0.339 \\
\hline HOMA & $3.3 \pm 0.3$ & $3.0 \pm 0.8$ & 0.005 & $4.2 \pm 0.4$ & $4.8 \pm 0.5$ & 0.273 \\
\hline Cholesterol (mg/dl) & $169.7 \pm 4.3$ & $158.5 \pm 4.5$ & 0.009 & $175.9 \pm 4.4$ & $170.7 \pm 3.7$ & 0.074 \\
\hline Triglycerides (mg/dl) & $106.2 \pm 9.5$ & $80.8 \pm 6.0$ & 0.001 & $120.3 \pm 10.4$ & $119.4 \pm 9.0$ & 0.364 \\
\hline Fasting glucose & $83.8 \pm 1.4$ & $88.8 \pm 4.5$ & 0.329 & $83.8 \pm 1.2$ & $85.8 \pm 1.1$ & 0.125 \\
\hline $\mathrm{HbA} 1 \mathrm{c}$ & $5.41 \pm 0.05$ & $5.39 \pm 0.04$ & 0.571 & $5.31 \pm 0.07$ & $5.43 \pm 0.04$ & 0.199 \\
\hline
\end{tabular}

children during a 1-year lifestyle intervention program. Carotid IMT is an ultrasonographic marker of atherosclerosis $(30,31)$, which is associated with coronary heart disease and hypertension in obese adults (32). In a previous study, we demonstrated that arterial abnormalities occur already as early as in childhood, although the mechanisms by which obesity affects IMT are yet unclear. Blood pressure, serum lipids, and glucose have all been found associating with IMT and have thus been discussed as a putative link between obesity and atherosclerosis (20). In this study, we confirmed an important association between serum lipids, glucose metabolism, and early vascular changes. However, our data suggest that in addition to these well-established parameters, early changes in IMT may also be associated with changes in serum PAPPA levels.

PAPPA levels did not differ between obese and lean children. However, despite this lack of association between BMI-SDS and serum PAPPA concentration, PAPPA levels decreased when participating in an intervention program, based on physical exercise, nutrition education, and behavior therapy. In subgroup analysis, PAPPA levels decreased in both groups with and without significant weight loss. Although we found a statistical trend toward lower serum PAPPA concentration after intervention in children with significant weight loss compared with children without weight loss, the mean decrease in PAPPA during the intervention did not reach statistical significance in children with significant weight loss. We assume that the lack of significant PAPPA decrease in children with weight loss results from the already lower baseline serum PAPPA concentration (1.65 vs $1.98 \mu \mathrm{U} / \mathrm{l}$ in the subgroup without weight loss (WL)).
Currently, no reference data on serum PAPPA levels in different pediatric age groups are available. In our sample, neither in univariate nor in multivariate analyses an association between age and PAPPA was observed. Therefore, we speculate that a weightindependent effect of the lifestyle program might modulate the observed decrease in PAPPA, which occurred in both subgroups (with or without weight loss). However, considering the small age range of our lean and obese patients' samples, we cannot definitely rule out an age-related decline in PAPPA, as so far no other study on serum PAPPA levels in healthy and/or obese children are available.

During the 1-year interval before and after participation, PAPPA, and IMT fell significantly for the whole group, although we cannot clearly attribute this decline to participation in the weight loss program, as we were only able to compare baseline data with a control group. As stated above, in both groups serum PAPPA concentrations after intervention were lower compared with baseline. Lipid levels fell significantly only in the group with weight loss, and only in this subgroup, PAPPA contributed significantly to the observed variance in IMT. This might indicate that in these patients, hyperlipidemia is of dominating importance regarding IMT and thereby masks a putative effect of PAPPA, which becomes apparent only after lifestyle intervention. In subgroup analysis comparing the groups with and without significant weight loss, we found a significant contribution of PAPPA levels to the variance of IMT after intervention only in individuals with weight loss. However, subgroup analyses lead to relatively small group sizes; therefore, these results warrant confirmation in larger sized cohorts. 

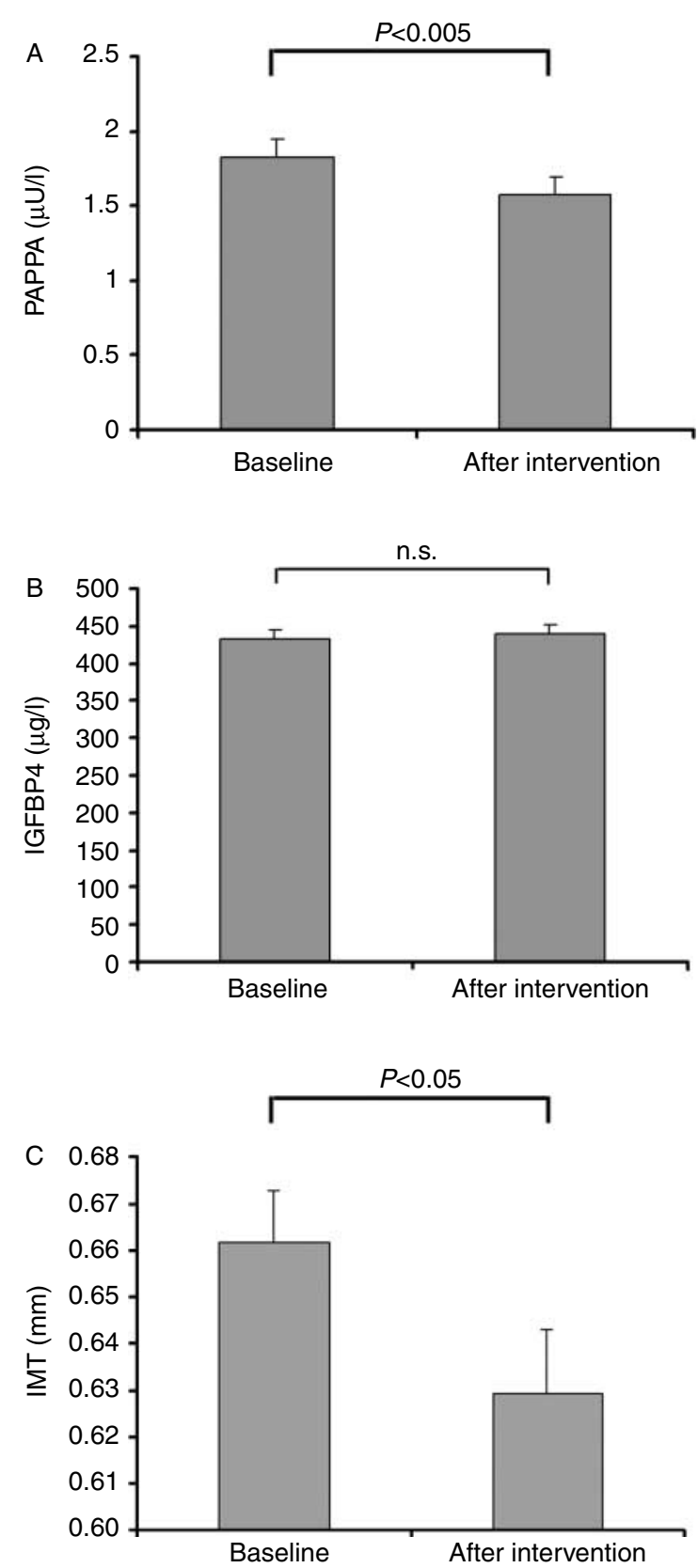

Figure 1 PAPPA (A) and IGFBP4 serum levels (B) and intima media thickness $(C)$ before and after participation in the weight loss program (mean and S.E.M.).

In addition to a correlation with IGF1 and serum PAPPA levels in our cohort of obese children correlated significantly with cholesterol and IGFBP1. This is in congruence with an observation of Aso et al. (18), who found serum cholesterol as an independent predictor of serum PAPPA concentrations in adult patients with type 2 diabetes. This association was additionally observed in asymptomatic hyperlipidemic subjects without clinical signs of atherosclerosis (33). In the animal model lacking ApoE, the additional knockout of PAPPA did not lead to differences in serum cholesterol, which might indicate that increased cholesterol stimulates PAPPA secretion rather than vice versa (34). However, in this study, in the longitudinal analysis, we found only a significant association between the change in PAPPA and the change in serum triglycerides, but not with the change in cholesterol levels. Thus, at the present point, we suggest that a causal relationship between PAPPA and serum lipids seems likely, but clearly further longitudinal studies including larger cohorts are required to shed more light on this interaction and putative mechanisms.

In contrast to a previous study (19), we did not find a significant correlation between $\mathrm{HbAlc}$ and PAPPA concentrations. However, both cohorts were hardly comparable, since in our group of obese, non-diabetic children, all HbA1c levels were within the normal range (mean HbA1c 5.4.\%), whereas the mentioned study cohort consisted of well-controlled diabetic adults (mean HbA1c 7.1\%; controls 5.2\%; reference (19)), so that HbA1c levels of our cohort were closer to the control than the study group.

Although in our study IGFBP1 correlated highly significantly to markers of insulin resistance HOMA and fasting insulin, a divergent picture was seen regarding the association of PAPPA with these parameters. In contrast to IGFBP4 and PAPPA did not show any association with HOMA or fasting insulin, but correlated highly significantly with IGFBP1. Although binding only a small fraction of circulating IGF1 and IGFBP1 is considered the only acute regulator of IGF1 bioavailability. Hepatic IGFBP1 expression is inversely related to the portal supply of insulin and reduced fasting serum IGFBP1 levels have been associated with hyperinsulinemia and related disorders in adults $(35,36)$. Previous studies indicated that a decrease in IGFBP1 levels might precede other indices of insulin resistance in childhood (37-39). However, whether the observed association between PAPPA and IGFBP1 indicates a role of PAPPA in the network influencing insulin sensitivity or is more related to the complex effects of PAPPA on IGFBPs currently remains unclear.

To date, the mechanisms through which PAPPA modulates initiation, maintenance, or progression of the atherosclerotic process remain largely unclear. Previous studies demonstrated that PAPPA acts as a protease and modulates circulating and potentially local IGF1 concentrations by cleaving at least three of six IGF binding proteins, thereby regulating IGF1 bioavailability. Furthermore, local IGF1 bioavailability has been linked to proliferation of vascular smooth muscle cells and modulation of local inflammatory processes, thereby putatively acting pro-atherogenic (40). Exposure of endothelial cells to the pro-inflammatory cytokine tumor necrosis factor $\alpha$ (TNF $\alpha)$ stimulated expression of PAPPA (41). Several animal models supported a pro-atherogenic role of PAPPA. Animals 
lacking PAPPA exhibit a longevity phenotype, with a 30\% increase in life span (42) and deletion of the Pappa gene in high-cholesterol-fed, ApoE-deficient animals resulted in a reduction of atheromatous lesions compared with wild-type littermates (36). Targeted disruption of the Pappa gene was associated with diminished smooth muscle cell response to IGF1 (43). In animals lacking PAPPA and IGF1 serum levels at 104 days of age were lower in both males and females, but this proved not to be of statistical significance (44). In our study, we found a negative correlation between serum levels for PAPPA and IGF1. However, in the current study in obese children, in none of which carotid plaques could be detected, serum IGF1 did not contribute significantly to the observed variance in IMT, neither before nor after intervention. These conflicting results are mirrored in a more recent debate, whether the PAPPA/IGF1 system indeed has a pro-atherogenic or, in the opposite, may play an anti-atherogenic role. Whereas PAPPA levels are increased in patients with unstable coronary or carotid plaques, the evidence of PAPPA as a pro-atherogenic factor in native arteries is low (reviewed in (45)). The same debate takes place for IGF1, with more recent studies demonstrating antioxidant, anti-inflammatory, and potentially atheroprotective effects of IGF1, as opposed to the more traditional view of locally produced IGF1 increasing the neointimal injury response (46). Thus, at present, the observed correlations between PAPPA in the cross-sectional analyses and the changes in the longitudinal part of our study cannot be linked to a clear negative or positive effect on vascular health.

The strength of this study lies in the dual approach of a combination of cross-sectional and longitudinal data. However, our study has a number of potential limitations. First, due to the small sample size of the lean control and ethical restrictions, we were only able to compare selective baseline parameters (PAPPA and IGFBP4), but not post-intervention results of obese children with a lean control group. Although we did not find an association between PAPPA and age, we cannot completely rule out that the observed decline in PAPPA after participation in the lifestyle program is related to the increase in age. Secondly, BMI percentiles were used to classify overweight. Although BMI is a good measure for overweight, one needs to be aware of its limitation as an indirect measure of fat mass. Thirdly, we are not able to differentiate the effect of diet, increased physical exercise, and weight loss on PAPPA or IGFBP4 concentrations due to our study protocol. Fourthly, we determined maximum IMT in this cohort, since in previous studies maximum IMT showed the strongest association to coronary risk factors in otherwise healthy individuals (30). However, we do not know whether our findings related to maximum IMT can be compared with studies using mean IMT determination. Fifthly, the observed associations between PAPPA and IMT, IGF1, cholesterol, and IGFBP1 do not prove a causal relationship, as we found only a significant correlation of the change in PAPPA with the change in triglycerides, but in none of the above-mentioned parameters. Additional longitudinal studies in healthy and obese subjects covering a larger age range and focusing on the mentioned parameters are required to validate the observations. Finally, as outlined in the Methods section, the assay we used includes an antibody pair that measures dimeric, uncomplexed PAPPA and PAPPA/proMBP in equimolar concentrations. This may explain differences between ours' and previous studies using assays that detect 'pregnancy' PAPPA in form of a covalent complex with pro-MBP.

In summary, in this cohort of obese children, serum PAPPA levels correlated significantly with other cardiovascular risk factors. Cross-sectionally, PAPPA correlated significantly with serum IGF1, IGFBP1, and cholesterol, and longitudinally the change of PAPPA was associated with the observed change of triglycerides. Whether these associations indicate a negative effect of PAPPA on vascular health in these obese children, either through a direct effect or through a more indirect mechanism of PAPPA with cardiovascular risk factors such as serum lipids, remains to be confirmed in subsequent studies.

\section{Declaration of interest}

The authors declare that there is no conflict of interest that could be perceived as prejudicing the impartiality of the research reported.

\section{Funding}

J Woelfle received grant support from Ipsen. T Reinehr received grant support (2008-2010) from of the German Ministry of Education and Research (Bundesministerium für Bildung und Forschung) Obesity network: LARGE, grant number 01 GI0839. C L Roth received grant support (2003-2004) from Bonfor Research Foundation, University of Bonn, Germany.

\section{Acknowledgements}

We thank Ms K Schark-Zimmer, Children's Hospital University of Bonn, for her kind support in the laboratory.

\section{References}

1 Lin TM, Halbert SP, Kiefer DJ, Spellacy WN \& Gall S. Characterization of four human pregnancy-associated plasma proteins. American Journal of Obstetrics and Gynecology 1974118 223-236.

2 Wald NJ, Watt HC \& Hackshaw AK. Integrated screening for Down's syndrome on the basis of tests performed during the first and second trimesters. New England Journal of Medicine 199912 461-467. (doi:10.1056/NEJM199908123410701)

3 Overgaard MT, Oxvig C, Christiansen M, Lawrence JB, Conover CA, Gleich GJ, Sottrup-Jensen L \& Haaning J. Messenger ribonucleic acid levels of pregnancy-associated plasma protein-A and the proform of eosinophil major basic protein: expression in human reproductive and nonreproductive tissues. Biology of Reproduction 199961 1083-1089. (doi:10.1095/biolreprod61.4.1083) 
4 Chen B-K, Leiferman KM, Pittelkow MR, Overgaard MT, Oxvig C \& Conover CA. Localization and regulation of pregnancy-associated plasma protein-A expression in healing human skin. Journal of Clinical Endocrinology and Metabolism 200388 4465-4471. (doi:10.1210/jc.2003-030193)

5 Bayes-Genis A, Conover CA, Overgaard MT, Bailey KR, Christiansen M, Holmes DR Jr, Virmani R, Oxvig C \& Schwartz RS. Pregnancy-associated plasma protein A as a marker of acute coronary syndromes. New England Journal of Medicine 2001345 1022-1029. (doi:10.1056/NEJMoa003147)

6 Lawrence JB, Oxvig C, Overgaard MT, Sottrup-Jensen L, Gleich GJ, Hays LG, Yates JR III \& Conover CA. The insulin-like growth factor (IGF)-dependent IGF binding protein-4 protease secreted by human fibroblasts is pregnancy-associated plasma protein-A. PNAS 199996 3149-3153. (doi:10.1073/pnas.96.6.3149)

7 Monget P, Mazerbourg S, Delpuech T, Maurel MC, Maniere S, Zapf J, Lalmanach G, Oxvig C \& Overgaard MT. Pregnancyassociated plasma protein-A is involved in insulin-like growth factor binding protein-2 (IGFBP-2) proteolytic degradation in bovine and porcine preovulatory follicles: Identification of cleavage site and characterization of IGFBP-2 degradation. Biology of Reproduction 200368 77-86. (doi:10.1095/biolreprod.102. 007609)

8 Rivera GM \& Fortune JE. Selection of the dominant follicle and insulin-like growth factor (IGF)-binding proteins: evidence that pregnancy-associated plasma protein A contributes to proteolysis of IGF-binding protein 5 in bovine follicular fluid. Endocrinology 2003144 437-446. (doi:10.1210/en.2002-220657)

9 Laursen LS, Overgaard MT, Soe R, Boldt HB, Sottrup-Jensen L, Giudice LC, Conover CA \& Oxvig C. Pregnancy-associated plasma protein-A (PAPP-A) cleaves insulin-like growth factor binding protein (IGFBP)-5 independent of IGF: implications for the mechanism of IGFBP-4 proteolysis by PAPP-A. FEBS Letters 2001504 36-40. (doi:10.1016/S0014-5793(01)02760-0)

10 Conover CA, Bale LK, Overgaard MT, Johnstone EW, Laursen UH, Füchtbauer E-M, Oxvig C \& van Deursen J. Metalloproteinase pregnancy-associated plasma protein $\mathrm{A}$ is a critical growth regulatory factor during fetal development. Development 2004 131 1187-1194. (doi:10.1242/dev.00997)

11 DeChiara TM, Efstratiadis A \& Robertson EJ. A growth-deficiency phenotype in heterozygous mice carrying an insulin-like growth factor II gene disrupted by targeting. Nature $1990 \mathbf{3 4 5} 78-80$. (doi:10.1038/345078a0)

12 Rehage M, Mohan S, Wergedal JE, Bonafede B, Tran K, Hou D, Phang D, Kumar A \& Qin X. Transgenic overexpression of pregnancy-associated plasma protein-A increases the somatic growth and skeletal muscle mass in mice. Endocrinology 2007148 6176-6185. (doi:10.1210/en.2007-0274)

13 Lund J, Qin QP, Ilva T, Pettersson K, Voipio-Pulkki LM, Porela P \& Pulkki K. Circulating pregnancy-associated plasma protein a predicts outcome in patients with acute coronary syndrome but no troponin I elevation. Circulation 2003108 1924-1926. (doi:10.1161/01.CIR.0000096054.18485.07)

14 Iversen KK, Dalsgaard M, Teisner AS, Schoos M, Teisner B, Nielsen H, Clemmensen P \& Grande P. Usefulness of pregnancyassociated plasma protein A in patients with acute coronary syndrome. American Journal of Cardiology 2009104 1465-1471. (doi:10.1016/j.amjcard.2009.07.017)

15 Heider P, Pfäffle N, Pelisek J, Wildgruber M, Poppert H, Rudelius M \& Eckstein $\mathrm{HH}$. Is serum pregnancy-associated plasma protein A really a potential marker of atherosclerotic carotid plaque stability ? European Journal of Vascular and Endovascular Surgery 201039 668-675. (doi:10.1016/j.ejvs.2010.03.012)

16 Domínguez-Rodríguez A, Abreu-González P, García-González M, Ferrer J \& Vargas M. Circulating pregnancy-associated plasma protein A is not an early marker of acute myocardial infarction. Clinical Biochemistry 200538 180-182. (doi:10.1016/j.clinbiochem.2004.10.015)

17 Qin QP, Kokkala S, Lund J, Tamm N, Qin X, Lepäntalo M \& Pettersson K. Immunoassays developed for pregnancyassociated plasma protein-A (PAPP-A) in pregnancy may not recognize PAPP-A in acute coronary syndromes. Clinical Chemistry $2006 \mathbf{5 2}$ 398-404. (doi:10.1373/clinchem.2005.058396)

18 Aso Y, Okumura K, Wakabayashi S, Takebayashi K, Taki S \& Inukai T. Elevated pregnancy-associated plasma protein-A in sera from type 2 diabetic patients with hypercholesterolemia: associations with carotid atherosclerosis and toe-brachial index. Journal of Clinical Endocrinology and Metabolism 200489 5713-5717. (doi:10.1210/jc.2004-0787)

19 Pellitero S, Reverter JL, Pizarro E, Pastor MC, Granada ML, Tassies D, Reverter JC, Salinas I \& Sammarti A. Pregnancyassociated plasma protein-A levels are related to glycemic control but not to lipid profile or hemostatic parameters in type 2 diabetes. Diabetes Care 200730 3083-3085. (doi:10.2337/dc07-1092)

20 Reinehr T, Kiess W, de Sousa G, Stoffel-Wagner B \& Wunsch R. Intima media thickness in childhood obesity relations to inflammatory marker, glucose metabolism, and blood pressure. Metabolism: Clinical and Experimental 200655 113-118.

21 Reinehr T, Kiess W, Kapellen T \& Andler W. Insulin sensitivity among obese children and adolescents, according to degree of weight loss. Pediatrics 2004114 1569-1573. (doi:10.1542/peds. 2003-0649-F)

22 Reinehr T, de Sousa G, Toschke AM \& Andler W. Long-term followup of cardiovascular disease risk factors in children after an obesity intervention. American Journal of Clinical Nutrition 2006 84 490-496.

23 Cole TJ, Bellizzi MC, Flegal KM \& Dietz WH. Establishing a standard definition for child overweight and obesity worldwide: international survey. BMJ 2000320 1240-1243. (doi:10.1136/bmj. 320.7244.1240)

24 Kromeyer-Hauschild K, Wabitsch M, Kunze D, Geller F, Ziegler A, Geiß HC, Hesse V, Hippel A, Jäger U, Johnsen D, Kiess W, Korte W, Menner K, Müller M, Niemann-Pilatus A, Remer T, Schäfer F, Wittchen HU, Zabransky S, Zellenr K \& Hebebrand J. Percentiles of body mass index in children and adolescents evaluated from different regional German studies. Monatsschr Kinderheilkd 2001 149 807-818. (doi:10.1007/s001120170107)

25 Cole TJ. The LMS method for constructing normalized growth standards. European Journal of Clinical Nutrition $1990 \mathbf{4 4} 45-60$.

26 Marshall WA \& Tanner JM. Variations in pattern of pubertal changes in girls. Archives of Disease in Childhood 196944 291-303. (doi:10.1136/adc.44.235.291)

27 Marshall WA \& Tanner JM. Variations in the pattern of pubertal changes in boys. Archives of Disease in Childhood 197045 13-23. (doi:10.1136/adc.45.239.13)

28 National High Blood Pressure Education Program Working Group on High Blood Pressure in Children and Adolescents. The fourth report on the diagnosis, evaluation, and treatment of high blood pressure in children and adolescents. Pediatrics $2004 \mathbf{1 1 4}$ 555-576. (doi:10.1542/peds.114.2.S2.555)

29 Matthews DR, Hosker JP, Rudenski AS, Naylor BA, Treacher DF \& Turner RC. Homeostasis model assessment: insulin resistance and beta-cell function from fasting plasma glucose and insulin concentrations in man. Diabetologia 198528 412-419. (doi:10. 1007/BF00280883)

30 Hurwitz Eller N \& Netterstrom B. The intima media thickness and coronary risk factors. International Angiology 200120 118-125.

31 Simon A, Gariepy J, Chironi G, Megnien JL \& Levenson J. Intimamedia thickness: a new tool for diagnosis and treatment of cardiovascular risk. Journal of Hypertension 2002 20 159-169. (doi:10.1097/00004872-200202000-00001)

32 Toikka JO, Laine H, Ahotupa M, Haapanen A, Viikari JS, Hartiala JJ \& Raitakari OT. Increased arterial intima-media thickness and in vivo LDL oxidation in young men with borderline hypertension. Hypertension 200036 929-933.

33 Beaudeux JL, Burc L, Imbert-Bismut F, Giral P, Bernard M, Bruckert E \& Chapman MJ. Serum plasma pregnancy-associated protein A: a potential marker of echogenic carotid atherosclerotic plaques in asymptomatic hyperlipidemic subjects at high cardiovascular risk. Arteriosclerosis, Thrombosis, and Vascular Biology 200323 e7-10. (doi:10.1161/01.ATV.0000047448.76485.B8) 
34 Harrington SC, Simari RD \& Conover CA. Genetic deletion of pregnancy-associated plasma protein-A is associated with resistance to atherosclerotic lesion development in apolipoprotein E-deficient mice challenged with a highfat diet. Circulation Research 200722 1696-1702. (doi:10.1161/CIRCRESAHA.106.146183)

35 Juul A. Serum levels of insulin-like growth factor I and its binding proteins in health and disease. Growth Hormone \& IGF Research 200313 113-170. (doi:10.1016/S1096-6374(03)00038-8)

36 Heald AH, Cruickshank JK, Riste LK, Cade JE, Anderson S, Greenhalgh A, Sampayo J, Taylor W, Fraser W, White A \& Gibson JM. Close relation of fasting insulin-like growh factor binding protein-1 (IGFBP-1) with glucose tolerance and cardiovascular risk in two populations. Diabetologia 200144 333-339. (doi:10.1007/s001250051623)

37 Motaghedi R, Gujral S, Sinha S, Sison C, Ten S \& Maclaren NK. Insulin-like growth factor binding protein-1 to screen for insulin resistance in children. Diabetes Technology and Therapeutics 20079 43-51. (doi:10.1089/dia.2006.0056)

38 Maddux BA, Chan A, De Filippis EA, Mandarino LJ \& Goldfine ID. IGF-binding protein-1 levels are related to insulin-mediated glucose disposal and are a potential serum marker of insulin resistance. Diabetes Care 200629 1535-1537. (doi:10.2337/dc05-1367)

39 Schreiner F, Gohlke B, Stutte S, Bartmann P \& Woelfle J. Growth hormone receptor $\mathrm{d} 3$-variant, insulin-like growth factor binding protein-1 575G/A polymorphism and postnatal catch-up growth: association with parameters of glucose homeostasis in former extremely low birth weight preterm infants. Growth Hormone and IGF Research 201020 201-204. (doi:10.1016/j.ghir.2010.01.002)

40 Delafontaine P, Song YH \& Li Y. Expression, regulation, and function of IGF-1, IGF-1R, and IGF-1 binding proteins in blood vessels. Arteriosclerosis, Thrombosis, and Vascular Biology 200424 435-444. (doi:10.1161/01.ATV.0000105902.89459.09)
41 Conover CA, Harrington SC \& Bale LK. Differential regulation of pregnancy associated plasma protein-A in human coronary artery endothelial cells and smooth muscle cells. Growth Hormone \& IGF Research 200818 213-220. (doi:10.1016/j.ghir.2007.09.001)

42 Conover CA \& Bale LK. Loss of pregnancy-associated plasma protein A extends lifespan in mice. Aging Cell 20076 727-729. (doi:10.1111/j.1474-9726.2007.00328.x)

43 Resch ZT, Simari RD \& Conover CA. Targeted disruption of the pregnancy-associated plasma protein-A gene is associated with diminished smooth muscle cell response to insulin-like growth factor-I and resistance to neointimal hyperplasia after vascular injury. Endocrinology 2006147 5634-5640. (doi:10.1210/en. 2006-0493)

44 Conover CA, Bale LK, Mader JR, Mason MA, Keenan KP \& Marler RJ. Longevity and age-related pathology of mice deficient in pregnancy-associated plasma protein-A. Journals of Gerontology. Series A, Biological Sciences and Medical Sciences 201065 590-599. (doi:10.1093/gerona/glq032)

45 Andreotti F, Rio T \& Conti E. Role of PAPP-A in atherothrombosis: messages to take home. Atherosclerosis 2009203 353-354. (doi:10.1016/j.atherosclerosis.2008.09.024)

46 Higashi Y, Sukhanov S, Anwar A, Shai SY \& Delafontaine P. IGF-1, oxidative stress and atheroprotection. Trends in Endocrinology and Metabolism 201021 245-254. (doi:10.1016/j.tem.2009.12. 005)

Received 28 February 2011

Revised version received 9 June 2011

Accepted 13 July 2011 